\title{
KEYAKINAN LANSIA TENTANG SEKSUALITAS PADA MASA LANJUT USIA
}

\author{
Elders Belief On Sexual In Elderly
}

\author{
Hubertus Agung Pambudi ${ }^{1}$, Meidiana Dwidiyanti ${ }^{2}$, Diyan Yuli Wijayanti ${ }^{3}$ \\ ${ }^{1}$ Magister Keperawatan, Fakultas Kedokteran, Universitas Diponegoro, Semarang, Indonesia \\ ${ }^{2,3}$ Departemen Keperawatan, Fakultas Kedokteran, Universitas Diponegoro, Semarang, Indonesia \\ Korespondensi: Hubert_ap@yahoo.co.id
}

\begin{abstract}
ABSTRAK
Seksualitas terbayangkan berkaitan dengan kecantikan fisik atau adanya sedikit daya tarik. Kedua hal ini sebagian besar menghilang bersamaan dengan semakin lanjutnya usia karena adanya perubahan pada kulit serta susunan jaringan ikat dan lemak. Tujuan penelitian ini untuk mengetahui keyakinan lansia tentang seksualitas pada masa lanjut usia di masyarakat RW 01 Kelurahan Pedalangan wilayah kerja Puskesmas Padangsari Banyumanik Semarang. Penelitian ini menggunakan desain penelitian kualitatif dengan pendekatan fenomenologi hermeneutic, suatu pendekatan yang mengasumsikan temuan-temuan risetnya tidak murni hasil deskripsi, tetapi lebih interprestasi peneliti. Adanya keyakinan yang menyatakan bahwa hubungan seksual dengan intensitas yang tinggi dapat membuat seseorang menjadi awet muda, namun hal ini tidak sepenuhnya dipercaya oleh partisipan. Partisipan lebih meyakini bahwa usia akan terus bertambah dan setiap orang akan tetap menjadi tua, namun melalui hubungan seksual suami istri adalah wujud atau bentuk kasih sayang terhadap pasangan, yang tentunya akan berimplikasi terhadap harmonisnya keluarga. Keyakinan lansia terhadap seksualitas pada masa lanjut usia adalah bukan untuk menjadi awet muda melainkan untuk menjaga keharmonisan keluarga.
\end{abstract}

Kata Kunci : Keyakinan seksualitas, lanjut usia.

\begin{abstract}
Sexuality is imaginable with regard to physical beauty or a slight attraction. Both of these have largely disappeared as age progresses because of changes in the skin and the makeup of fatty tissue and fat. This study aimed to know the elderly beliefs about sexuality in the elderly in community RW 01 Pedalangan working area of Puskesmas Padangsari Banyumanik Semarang. This study used a qualitative research design with a hermeneutic phenomenology approach, an approach which assumes that the research findings are not purely descriptive, but rather the interpreter's interpretation. The belief that high-intensity sexual intercourse can make a person stay young, but this is not entirely trusted by participants. Participants believe that age will continue to grow and everyone will still grow old, but through sexual intercourse husband and wife is as a form or form of affection towards the couple, which of course will have implications for the harmonious family. Elderly belief in sexuality in the elderly is not to be ageless but to maintain family harmony.
\end{abstract}

Keywords : Sexuality belief, Elderly. 


\section{Pendahuluan}

Penuaan dicirikan dengan kehilangan banyak sel tubuh dan penurunan metabolisme yang ada pada sel lainya. Proses penuaan menyebabkan akan penurunan fungsi tubuh dan adanya perubahan dari komposisi tubuh. Perubahan bertahap pada fungsi tubuh yang normal akan menyertai proses penuaan pada sistem tubuh manusia, dan akan timbul perubahan terkait usia (Stockslager \& Schaeffer, 2008). Pada tahun 2000 jumlah lansia diperkirakan sebesar 7,28\% dan pada tahun 2020 sebesar $11,34 \%$. Dari data USA-Bareau of the Census, bahkan menurut Kinsella \& Taeuber 1993, Indonesia diperkirakan akan mengalami pertumbuhan jumlah lansia terbesar di seluruh dunia, antara tahun 19902025, yaitu sebesar 414\% (Darmojo \& Martono, 2010).

Seksualitas berdasarkan WHO adalah suatu aspek inti manusia sepanjang hidupnya meliputi seks, identitas dan peran gender, orientasi seksual, erotisisme, kenikmatan, kemesraan, dan reproduksi. Seksualitas dialami dan diungkapkan dalam pikiran, khayalan, gairah, kepercayaan, sikap, nilai, perilaku, perbuatan, peran dan hubungan. Seksualitas dipengaruhi oleh interaksi faktor biologis, psikologis, sosial, ekonomi, politik, budaya, etika, hukum, sejarah, religi, dan spiritual (World Health Organization, 2006). Perubahan pada lansia juga mempengaruhi seksualitas kehidupan manusia. Seksualitas berperan dalam menentukan kualitas hidup lansia, sehingga mempertahankan seksualias pada lansia penting dalam mewujudkan kebahagiaan keluarga, meskipun dalam kapasitas seksualitas mengalami penurunan (Hamid, 2008).

Hasil pengkajian aplikasi komunitas pada tanggal 27 Oktober-4 Nopember 2016 terhadap 41 lansia berumur 60-69 tahun yang berpasangan di RW 01 Kelurahan Pedalangan Kecamatan Banyumanik Semarang, dengan instrumen pengkajian kuesioner berdasarkan
Teori Self Care, didapatkan hasil dari pertanyaan pengkajian lansia berdasarkan keyakinan hubungan suami istri pada lanjut usia dapat membuat awet muda, 16 lansia $(39,02 \%)$ menjawab selalu, 13 lansia (31,71\%) menjawab kadang-kadang, 7 lansia $(17,07 \%)$ menjawab tidak pernah dan 5 lansia $(12,20 \%)$ jarang.

Seksualitas dalam arti yang luas ialah semua aspek badaniah, psikologik, dan kebudayaan yang berhubungan langsung dengan seks dan hubungan seks manusia. Dalam arti sempit sebagai sarana untuk penciptaan keturunan (prokreasi) dimana dalam seks terjadi suatu potensi alami yang mengarah pada persatuan pria dan wanita, atau dengan kata lain suatu keterarahan alami antara pria dan wanita untuk bersatu dan menghasilkan keturunan. Dalam peradaban manusia, seks biasanya merupakan bagian dari suatu lembaga perkawinan (Theris A. Touhy, 2015).

Berdasarkan hasil wawancara dengan perawat pemegang program lansia di RW 01 Kelurahan Pedalangan Kecamatan Banyumanik Semarang wilayah kerja Puskesmas Padangsari Banyumanik Semarang, tidak ada keluhan atau cerita dari lansia tentang kehidupan hubungan suami istri. Hal ini menunjukkan tertutupnya pengalaman hubungan suami istri pada lansia dalam menjalani kehidupan di usia lanjut.

\section{Tujuan}

Tujuan penelitian ini untuk mengetahui keyakinan lansia tentang seksualitas pada masa lanjut usia di masyarakat RW 01 Kelurahan Pedalangan wilayah kerja Puskesmas Padangsari Banyumanik Semarang.

\section{Metode}

Penelitian ini menggunakan desain penelitian kualitatif dengan pendekatan fenomenologi hermeneutic, suatu 
pendekatan yang mengasumsikan temuantemuan risetnya tidak murni hasil deskripsi, tetapi lebih interprestasi peneliti (Afiyanti \& Nurahmawati, 2014; Creswell, 2015).

Strategi pemilihan sampel yang digunakan dalam penelitian ini adalah criterion sampling, yaitu bertujuan untuk memperoleh sampel yang memenuhi kriteria tertentu dan berguna untuk menjamin kualitas sampel (Creswell, 2015; Satori \& Komariah, 2009). Dalam hal ini partisipan yang diambil lansia berusia 60-74 tahun yang mempunyai pasangan hidup yang sah dan bersedia menjadi partisipan dengan memberikan persetujuan, mampu dan mau menceritakan persepsi seksualitas.

Instrumen penelitian yang digunakan adalah kuesioner. Kueisioner yang digunakan adalah pertanyaan tentang keyakinan lansia tentang seksualitas pada lanjut usia. Pengambilan data dengan melakukan wawancara yang mendalam kepada partisipan lansia sesuai dengan kriteria yang ditetapkan.

Membuat transkrip data, menyusun hasil wawancara dengan cara mendeskripsikan hasil rekaman dalam bentuk verbatim, kedua menilai keakuratan hasil wawancara dengan mendengarkan kembali hasil wawancara dan mencocokkan dengan membaca transkrip verbatim serta mengintegrasikan hasil catatan lapangan ke dalam transkrip.

Membaca hasil transkrip berulang-ulang, untuk mendapatkan pemahaman yang tepat dari hasil wawancara dan untuk mengidentifikasi pernyataan yang bermakna dari setiap partisipan. Pernyataan dari setiap partisipan yang bermakna berdasarkan catatan lapangan saat dilakukan penelitian disebut sebagai kata kunci.

Mengulang semua proses untuk semua hasil transkrip partisipan yang kemudian menentukan kategori. Semua pernyataan yang memiliki makna yang sama atau hampir sama dijadikan dalam satu kategori.

Memahami berbagai kategori secara utuh dan menelusuri tema yang kemungkinan muncul. Kategori yang sudah didapatkan, menjadikan pernyataan yang bermakna dan saling berhubungan sehingga dapat dijadikan sub tema. Kategori yang sejenis dan terkait dirumuskan dalam bentuk tema.

Mengintegrasikan hasil secara keseluruhan ke dalam bentuk deskriptif naratif yang lengkap, sistematis, jelas dalam hasil penelitian.

Mengklarifikasi hasil deskriptif analisis data yang telah dibuat dengan mengembalikan kepada partisipan untuk memastikan apakah sudah sesuai dengan apa yang disampaikan kepada peneliti. Pada tahap ini peneliti memvalidasi ke partisipan dengan datang kembali ke rumah partisipan.

Semua partisipan dalam penelitian ini telah memperoleh penjelasan tentang tujuan dan manfaat penelitian. Penjelasan diberikan secara lisan dan tertulis. Penelitian ini telah melalui pemeriksaan etik dari Komisi Etik Penelitian Kesehatan Fakultas Kedokteran Universitas Diponegoro dan RSUP dr Kariadi Semarang beralamat di Gedung Dekanat Lama Fakultas Kedokteran Universitas Diponegoro Lantai 1, Jalan Dokter Sutomo 18 Semarang. Ethical Clearence disetujui dan ditandatangani tanggal 31 Juli 2017 dengan Nomor: 480/EC/FKRSDK/VII/2017.

\section{Hasil}

Adanya kepercayaan yang menyatakan bahwa hubungan seksual dengan intensitas yang tinggi dapat membuat seseorang menjadi awet muda, namun hal ini tidak sepenuhnya dipercaya oleh partisipan. Partisipan lebih meyakini bahwa usia akan 
terus bertambah dan setiap orang akan tetap menjadi tua, namun melalui hubungan seksual suami istri adalah sebagai wujud atau bentuk kasih sayang terhadap pasangan, yang tentunya akan berimplikasi terhadap harmonisnya keluarga. Berikut hasil kutipan wawancara dengan partisipan tentang kepercayaan tentang efek yang dapat ditimbulkan dalam hubungan seksualitas.

"Kalau membuat awet muda tidak, tetapi untuk membuat bahagia dalam berumahtangga saya percaya" (PI)

"Membuat awet muda itu tidak, tapi kalau membuat bahagia dalam berumah tangga itu jelas" (P2)

"Kalau untuk membuat bahagia dalam berumah tangga itu saya percaya” (P3)

Berdasarkan hasil wawancara di atas dapat dipahami bahwa sebenarnya hubungan seksualitas pada lansia bukan hanya sebagai pemuas hasrat semata, namun lebih dalam bentuk menjaga kebahagiaan dan keharmonisan keluarga.

\section{Pembahasan}

Hasil penelitian menemukan bahwa hubungan seksual tidak dapat membuat seseorang menjadi awet muda, karena usia seseorang akan terus bertambah dan tidak dapat dipungkiri bahwa semakin lama setiap orang akan menjadi tua dengan kemampuan fisik dan psikologis yang semakin menurun. Namun demikian, keintiman suami istri walaupun sudah lanjut usia ternyata mampu membawa kebahagiaan dan kehangatan dalam rumah tangga sehingga rumah tanggapun akan tetap harmonis hingga satu pasangan berlanjut usia.

Bentuk romantis yang dilakukan pasangan lansia ini bisa dilihat dari segi sosial dimana pasangan lansia ini terlihat selalu bersama, menjalin komunikasi dengan baik dan saling memberikan perhatian kepada pasangannya, sehingga masyarakatpun dapat melihat kedekatan pasangan lansia tersebut. Ketika pasangan menerapkan rasa kebersamaan dan dapat berbagi waktu aktivitas maka akan meningkatkan hubungan dari hari ke hari sehingga lama kelamaan akan merasa hubungannya lebih intim. Semakin bertambahnya usia semakin lebih banyak waktu untuk berduaan. Kebersamaan tersebut yang membuat pasangan partisipan menjadi terlihat tetap romantis. Selain itu, dengan menghabiskan waktu bersama pasangan setiap hari akan menjadikan keluarga menjadi harmonis, seperti pada penelitian dilakukan oleh Anindita \& Bashori ketika pasangan suami istri selalu meluangkan waktu untuk mengisi dengan kegiatan bersama seperti menonton televisi dan bercengkerama dengan anak, seringnya pasangan suami istri melakukan kegiatan maka dapat meningkatkan kohesifitas. Salah satu bentuk romantis cinta yang dilakukan pasangan kekasih adalah menjalin sebuah komunikasi yang baik, sehingga dapat berbagi gagasan, pemikiran, perasaan dan tindakan dengan pasangan (Anindita \& Bashori, 2012).

Ungkapan kasih sayang dapat diberikan kepada pasangannya dalam bentuk perhatian. Hal ini merupakan salah satu bentuk dari dukungan pasangan bila dirasakan, dipersepsikan dan dinilai, dengan itu semua pasangan akan merasa memperoleh dukungan dan merasa bahwa pasangannya dapat diandalkan pada saat dibutuhkan, kondisi ini pasangan akan merasa puas dengan pernikahannya. Selain itu, perhatian yang diberikan secara penuh kepada pasangan membuat berkurangnya kecemasaan terhadap pasangan suami istri (Anindita \& Bashori, 2012).

Pasangan yang romantis memiliki hubungan yang dekat dengan pasangan dan memiliki 
sebuah komitmen untuk mempertahankan hubungan. Apabila pasangan suami istri dapat menjalin hubungan tersebut, maka terhindar dari rasa cemas dan ketidakpercayaan. Adapun bentuk keromantisan yang lainnya dapat dilihat bahwa bentuk romantis dalam sebuah hubungan yaitu saling berbagi, saling memberikan dukungan, saling memberikan kontak fisik dan seksual, serta adanya sebuah komitmen dalam hubungan. Terlihat bahwa komitmen termasuk salah satu bentuk yang perlu dijaga untuk mempertahankan sebuah hubungan. Setiap pasangan memiliki komitmen yang berbeda-beda untuk menjaga hubungannya seperti kesetiaan, kejujuran, kepercayaan, dan lainnya sehingga hubungan pasangan lansia ini bisa bertahan sampai saat ini. Salah satu komitmen yang ada pada pasangan untuk menjaga sebuah hubungan informan satu sama lain yaitu saling menghormati, saling menyayangi, keterbukaan, dan saling mengerti satu sama lain. Seks merupakan kebutuhan manusia hidup, itu memang sudah menjadi kenyataan. Rasanya tidak ada orang normal yang mampu hidup bahagia tanpa terpenuhi kebutuhan seksnya (Irianto, 2014)

Ketika cinta romantis dapat dipertahankan sampai hubungan jangka panjang maka akan muncul bentuk-bentuk romantis cinta yang dibutuhkan seperti sebuah komitmen, perasaan percaya, peduli, pengertian, kesadaran diri sendiri, dan yang lainnya. Dari perhatian yang diberikan kepada pasangannya peneliti melihat dari hasil observasi bahwa ketika makan, mengambilkan makanan, membantu mengambilkan pakaian, dan mengantarkan istri berpergian. Hal tersebut terlihat dalam bentuk di dalam penelitian yang didapat adalah komitmen dan perhatian, dimana di dalam sebuah perhatian sudah termasuk dalam kepedulian, dan kesadaran dalam tugas sebagai istri dan suami (Varma \& Mathur, 2015)

\section{Kesimpulan}

Keyakinan lansia terhadap seksualitas pada masa lanjut usia adalah bukan untuk menjadi awet muda melainkan untuk menjaga keharmonisan keluarga.

\section{Daftar Pustaka}

Afiyanti, Y., \& Nurahmawati, I. (2014). Metedologi Penelitian Kualitatif Dalam Riset Keperawatan (1st ed.). Jakarta: PT Raja Grafindo Persada.

Anindita, D., \& Bashori, K. (2012). Kohesivitas Suami Istri Di Usia Madya. Humanitas, IX No 1 .

Creswell, J. W. (2015). Penelitian Kualitatif dan Desain Riset: Memilih di Antara Lima Pendekatan. (S. Z. Qudsi, Ed.) (3rd ed.). Yogyakarta: Pustaka Pelajar.

Darmojo, B., \& Martono, H. (2010). Buku Ajar Ilmu Kesehatan Usia Lanjut (IV). Jakarta: Fakultas Kedokteran Universitas Indonesia.

Hamid, A. (2008). Bunga Rampai: Asuhan Keperawatan Jiwa. Jakarta: EGC.

Irianto, K. (2014). Seksologi Kesehatan. Bandung: Penerbit Alfabeta.

Satori, D., \& Komariah, A. (2009). Metode Penelitian Kualitatif. Bandung: Alfabeta.

Stockslager, J. L., \& Schaeffer, L. (2008). Buku Saku Asuhan Keperawatan Geriatrik (Edisi 2). Jakarta: Penerbit Buku Kedoktern. EGC.

Theris A. Touhy, K. F. J. :Ebersole \& H. P. (2015). Toward Health Aging: Human Needs and Nursing Response,.

Varma, P., \& Mathur, D. A. (2015). Adolescent Romantic Relationships. The International Journal of Indian Psychology, 3(1).

World Health Organization. (2006). Defining Sexual Health: Report of Technical Consultation on Sexual Health 28-31 January 2002, Geneva. Sexual Health Document Series.

Simatupang, M.R., 2009. Pengaruh Pola Konsumsi, Aktivitas Fisik dan Keturunan terhadap Kejadian Obesitas pada Siswa Sekolah Dasar Swasta di Kecamatan Medan Baru Kota Medan. 
Hubertus Agung Pambudi : Keyakinan Lansia Tentang Seksualitas Pada Masa Lanjut Usia Di Wilayah Kerja Puskesmas Padangsari Banyumanik Semarang

Sinclair, A.J. et al., 2010. Caring for older adults with diabetes mellitus: Characteristics of carers and their prime roles and responsibilities. Diabetic Medicine, 27(9), pp.10551059.

Sujaya, I.N., 2009. Pola Konsumsi Makanan Tradisional Bali sebagai Faktor Risiko Diabetes Melitus Tipe 2 di Tabanan. Jurnal skala husada, 6(1), pp.75-81.

Taylor, 2006. Health Psychology, McGrawHill Education (India)

Tjokroprawiro, A., 2003. Diabetes mellitus: kelasifikasi, diagnosis dan terapi, Gramedia Pustaka Utama.

Townsend, M.C., 2012. Psychiatric Mental Health Nursing: Concepts of Care in Evidence-based Practice, F.A. Davis Company.

Trisnawati, S.K. \& Setyorogo, S., 2013. Faktor Risiko Kejadian Diabetes Melitus Tipe II Di Puskesmas Kecamatan Cengkareng Jakarta Barat Tahun 2012. Jurnal Ilmiah Kesehatan, 5(1), pp.6-11. 